\title{
Challenges Affecting Establishment and Sustainability of Tourism Public Private Partnerships in Zimbabwe
}

\author{
Judias Peter Sai ${ }^{1}$, Noel Muzondo ${ }^{2} \&$ Edmond Marunda ${ }^{1}$ \\ ${ }^{1}$ Department of Tourism, Leisure and Hospitality Studies, University of Zimbabwe, Zimbabwe \\ ${ }^{2}$ Department of Business Studies, University of Zimbabwe, Zimbabwe \\ Correspondence: Noel Muzondo, Department of Business Studies, University of Zimbabwe, Zimbabwe. E-mail: \\ noelmuzondo@gmail.com
}

$\begin{array}{lc}\text { Received: September 4, } 2014 & \text { Accepted: September 4, } 2015 \quad \text { Online Published: September 17, } 2015 \\ \text { doi:10.5539/ass.v11n23p35 } & \text { URL: http://dx.doi.org/10.5539/ass.v11n23p35 }\end{array}$

\begin{abstract}
Public Private Partnerships (PPPs) provide governments and businesses with a unique cooperation framework for mutual gain. The major goal of this paper is to identify the challenges influencing the establishment and sustainability of PPPs in the tourism sector in Zimbabwe. Nine variables impeding the establishment and sustainability of PPPs were identified from a critical review of existing literature. A survey of public and private sector organisations that participated in the 2013 edition of the Zimbabwe International Tourism and Travel Fair confirmed that only three of the variables in the theoretical framework were challenges. Consequently, the paper offers a tentative empirical model of tourism PPP establishment and sustainability with two sets of independent variables i.e. challenges and other variables. The academic implications for the study are that future studies should test the tentative model and investigate the determinants of successful PPP establishment and sustainability in general. At least two public policy implications for the government and its agencies can be drawn from this study. To successfully court businesses into PPPs the government needs to, ideally, take into consideration private sector views in fine-tuning its PPP policies. The government also needs to educate its administrative agencies to appreciate that PPPs can be established in any area including mega events and destination marketing.
\end{abstract}

Keywords: exhibitions, destination marketing, mega events, public private partnerships, tourism, Zimbabwe

\section{Introduction}

Tourism as a socio-economic activity has received a lot of attention from researchers worldwide (Vijayanand, 2013; De Lacey et al., 2002). It has developed as one of the biggest and fastest growing industries in the world (World Travel \& Tourism Council, 2012). National economies enjoy a number of benefits from tourism, which include regional economic development in regions that would have remained underdeveloped had it not been for tourism (De Lacey et al., 2002), employment creation and overall national economic growth (Mhizha, Mandebvu, \& Muzondo, 2012, p. 7).

According to the Zimbabwe Tourism Authority (ZTA), tourism is a major contributor to Zimbabwe's Gross Domestic Product (GDP). The tourism sector contributed about 10 percent to the country's GDP in 2012 (ZTA, 2012) and its contribution to the economy may grow to 15 percent by 2015 (Zimbabwe National Budget Statement, 2014, p. 41). The Southern African Development Community (SADC) states that Zimbabwe has one of the most diversified tourism resource bases in the region but very little tourism development has taken place in the country since 1996 because of inadequate support and few promotional activities for the sector (www.sadc.int/member-states/zimbabwe, 2014). Budgetary constraints in government present a big challenge to sustainable tourism development in Zimbabwe today; huge sums of money are needed for tourism infrastructural development in the country. Many countries are in the same situation as national budgets are never adequate. In order to generate the much-needed revenue through tourism, there is a need to improve and/or rebuild the entire infrastructure necessary for tourism inflows. Apart from infrastructure, the tourism industry should improve its tourism marketing and promotion systems and practices in order to be more effective and efficient. All this calls for cooperation among the key stakeholders in the industry. One of the most viable avenues for such cooperation nowadays is the Public Private Partnerships (PPPs). Sustainable tourism development in Zimbabwe requires this type of cooperation as it brings together 'a series of stakeholders' interests and concerns' (Vijayanand, 2013) in 
pursuit of the common goal of tourism development.

A PPP is a long-term contractual arrangement between a public sector agency and a private sector concern, whereby resources and risk are shared for the purpose of developing a public facility (Akintoye et al., 2003). This definition is echoed by the Organisation for Economic Cooperation and Development (OECD). A PPP is a long term contractual arrangement between a public authority and a private partner whereby the private partner finances and delivers public services using capital assets and sharing associated risks (OECD, 2012). Other terms used for PPP arrangements include private sector participation (Asian Development Bank, 2008) and 'creative alliances' between government and private sector (Gabriela et al., 2013). Well-known examples of PPPs are found in infrastructure development, regional development, mega-event activation, marketing and promotion, crisis recovery, safety and security systems and economic recovery among others (Ng \& Wong, 2006; Asian Development Bank, 2008; Mendiratta, 2010).

The benefits of PPPs highlighted in the literature include access to investment, good for planning and implementation, cost effective, better project performance, saving on human resources and administrative time and cost, success in projects, increase in competitive situation and advantage and customer public satisfaction (Ng \& Wong, 2006; Vijayanand, 2013). The PPP concept has become a global phenomenon. In 2010, a total of 231 infrastructure projects with private participation and investment commitments of US\$170 billion in 41 countries were recorded by World Bank Group in the Private Participation in Infrastructure (PPI) Data Update Note No. 55 (Izaguire, 2011). Of this total investment commitment, sub Saharan Africa accounted for only $\$ 12.6$ billion, the same figure as for 2009 but a drop from $\$ 13.5$ billion in 2008 (Izaguire, 2011).

The Zimbabwe government has positioned itself as an advocate for the recognition and implementation of PPPs as a vehicle for national development (Short Term Emergency Recovery Programme, 2009; Zimbabwe National Budget Statement, 2013; Zimbabwe Agenda for Sustainable Socio-Economic Transformation 2013-2018). PPP arrangements are an effective avenue of spearheading various development projects in the country (Zimbabwe National Budget Statement, 2012, p. 146). This is particularly so given the huge amount of financial resources needed, which are beyond the government's capacity. Projects which are candidates for PPP participation in Zimbabwe are in the following sectors: energy, water, roads, information technology, railways, and civil aviation (Zimbabwe National Budget Statement, 2014, p. 106). The tourism sector benefits from this infrastructure and this may translate into overall competitiveness of Zimbabwe as a tourism destination. To attract more tourists destinations need aggressive marketing strategies. Asian Development Bank (2008) and Mendiratta (2010) suggest that PPPs can be initiated to manage marketing and promotion campaigns including organising mega events.

Whereas the Zimbabwe government has expressed its willingness to establish PPPs, academics in the country are yet to support this emerging policy option by researching the feasibility, nature and challenges of this national development avenue. Zimbabwe's PPP policy could be improved if the government could have access to research findings on issues pertaining to how PPPs are perceived by domestic and foreign private sector players. Consequently, this paper is an attempt to plug that gap. The paper does so by exploring the challenges affecting the establishment and sustainability of tourism PPPs in Zimbabwe focusing on how the country as a tourist destination is being marketed through exhibitions. Therefore, the paper is of benefit not only to policy makers and managers in the tourism sector but also academics and students in tourism marketing. Studies carried out in other countries in recent years have revealed a number of challenges hindering the successful establishment and implementation of PPPs. Some of the common challenges highlighted in extant literature include the need for incentives, lack of funding, policy and legal aspects, risk management, staff or employee issues, lack of experience and expertise, and attitudes of participants (Gabriela et al., 2013; Guzman \& Sierra, 2012; Grigorescu, 2008; Ng \& Wong, 2006; Thomsen, 2005; Sader, 2000). Given these challenges, the major goal of this study is to identify the challenges affecting the establishment and sustainability of PPPs in the tourism sector in Zimbabwe and the minor goal is to ascertain the gap, if any, in perceptions between the public and private sectors on impediments to the sustainability of tourism PPPs in the country.

From this section the paper is structured as follows. First, a brief description of the tourism and hospitality industry in Zimbabwe is given focusing on public and private players in the sector and how these stakeholders interact in managing the country's prime international tourism exhibition, Sanganai/Hlanganani Travel Fair. The description exposes the gaps in the management of this exhibition. Second, existing literature on PPPs is critically reviewed briefly. Third, the methodology used to gather data to achieve the goals of this paper is explained. Lastly, the findings of the study are presented, discussed and conclusions and implications presented. 


\section{The Tourism Industry and Management of Exhibitions in Zimbabwe}

The tourism and hospitality industry in Zimbabwe comprises many internal stakeholders - public and private. Essentially, the stakeholder groups in this industry are the ZTA which represents the public sector and the Zimbabwe Council for Tourism (ZCT) which represents the private sector. Like in other countries, the tourism industry in Zimbabwe relies on various marketing tools one of which is exhibitions.

\subsection{Zimbabwe's Tourism and Hospitality Industry}

As already stated, the tourism and hospitality industry in Zimbabwe is represented by the ZTA and ZCT. The ZTA is the national tourism management and promotion organisation set up by the Zimbabwe government in terms of the Tourism Act 1996 (Chapter 14:20) to promote, plan, develop, research and enforce standards within the industry and at the same time to market the country as a tourist destination. So the organisation is responsible for organizing mega events such as tourism trade fairs, promotions, road shows, workshops, and conferences to market the country. One of the international expositions the ZTA organises every year is the Sanganai/Hlanganani Travel Fair. The ZTA is relies on government funding through levies from the tourism sector. It is not in the best of financial position given the economic challenges Zimbabwe is facing since the late 1990s. As a result, the organisation's ability to effectively organise and run mega events like the Sanganai/Hlanganani Travel Fair is most likely to be compromised.

Countries as destinations have many internal stakeholders (Moilanen \& Rainisto, 2009; Anholt, 2005; Antonsen, 2010; Blain, Levy, \& Ritchie, 2005; Dinnie, 2009; Dinnie \& Fola, 2009; Kasabov \& Sundaram, 2011; Kavaratzis, 2012; Kim, 2011; Sartori, Mottironi, \& Corigliano, 2012) which must participate in destination marketing activities if the destinations are to achieve their marketing goals. Therefore, one of the areas which should be prioritised for PPP in Zimbabwe is destination marketing and in particular the organising of trade fairs such as Sanganai/Hlanganani Travel Fair.

The ZCT is the umbrella representative body of the private sector in the tourism and hospitality industry in Zimbabwe. It was founded in 1988 as the voice of the tourism and hospitality sector. The council comprises various stakeholder groups which are sub sector representative associations such as the Hospitality Association of Zimbabwe (HAZ) representing hotels, Association of Zimbabwe Travel Agents (AZTA), Board of Airline Representatives (BAR), Boating Association of Zimbabwe (BAZ), Catering Employers Association of Zimbabwe (CEAZ), Inbound Tour Operators of Zimbabwe Association (ITOZA), Safari Operators Association of Zimbabwe (SOAZ), Zimbabwe Vehicle Rental Association (ZVRA), and the Zimbabwe Tour Operators Association (ZTOA). The objectives of the ZCT are, among others, to be the private sector representative where tourism and hospitality issues are discussed, be the private sector arm to stimulate the design and coordination of Zimbabwe's strategic tourism planning and marketing efforts, and create an environment conducive to investment, development and growth of the tourism and hospitality industry.

\subsection{Sanganai/Hlanganani Travel Fair}

The tourism and hospitality industry in Zimbabwe is characterised by many mega-events among them trade fairs. An exhibition or trade fair is a place where manufacturers and retailers of a certain product category or sector meet each other to talk about trade, to present and demonstrate their products and services, to exchange ideas and do networking and actually buy and sell products (de Pelsmacker et al., 2001). Fairs are defined as regularly scheduled events where companies meet their customers and other important parties of their industry (Kellezi, 2013). Holloway (1994) states that trade fairs play an important role in the tourism and hospitality industry as they provide business opportunities between buyers and sellers. Trade fairs are events which have a key role in international, national and regional tourism marketing strategies, their primary function being to provide the host community with an opportunity to secure high prominence in the tourism market place (Hall, 1995). Trade fairs also bring business to hotels around the fair sites as fair participants will need accommodation and other hospitality services. Hotels are normally fully booked in Harare and Bulawayo, Zimbabwe, whenever these major fairs take place in the cities. Thus fairs contribute enormously to the economy every year.

The significance of trade fairs in the tourism industry is illustrated by the many tourism and travel fairs that take place annually in different parts of the world. Several fairs have gained international significance and recognition such as the International Tourism Bourse held every March in Berlin, the World Travel Market hosted every November in London, the South African Tourism Indaba presented every May in Durban, and the Zimbabwean Sanganai/Hlanganani Travel Fair normally held in October every year. The active involvement of state authorities in the planning, sponsoring, marketing and management of these trade fairs indicates that they are of important national and global interest. In the tourism industry, state authorities such as the National Tourism Organizations (NTOs) take the role of trade show organizers and have been involved in trade fair marketing and 
management for over five decades (Middleton et al., 2009). In Zimbabwe, the Sanganai/Hlanganani Travel and Tourism Fair is an example of an exposition organized by a state agency, the ZTA. Trade fairs are also used by governments as tools for supporting exporting industries as they make it possible for exporting companies to reach customers and test the market acceptability of their products at a reasonable cost (Serringhaus \& Rosson, 1994). In travel trade fairs, the NTOs incentivize foreign industrial buyers from tourist generating regions to attend trade shows hosted in tourist receiving regions by subsidizing travelling and accommodation costs hence bringing the tour operators and travel agents at the turf of the local suppliers (Middleton et al., 2009).

The tourism industry is regarded as an invisible export industry as it generates foreign currency for the economy through sale of local services to visitors in foreign currency. Considering that the tourism sector is a high growth industry that governments seek to develop, and that trade fairs are an important tool being used to promote the industry, it is important to create sustainable partnerships between public and private sector players. For this to be achievable, it is critical to identify the challenges that are faced in trying to forge sustainable PPPs in the industry and to put in place policies for sustainable PPPs.

In Zimbabwe the private sector in the tourism industry, represented by the ZCT, is involved in organizing the provision of accommodation, transport and other hospitality and travel services for trade fairs. This promotes the sector's business in a big way. However, the very private sector is not really involved in planning and organising trade fairs. This is done by the ZTA. The Sanganai/Hlanganani Travel and Tourism Fair has been recognized by the government and industry stakeholders as a marketing tool critical in promoting Zimbabwe's image on the international scene. This recognition is evidenced by the level of government involvement in planning, marketing and management of the fair through the Ministry of Tourism and the ZTA. The fair has grown over the years to become one of the leading tourism showcases in Africa (www.zimbabwetourism.net/index.php/festivals-events/sanganai-hlanganani).

The performance of trade show organizers is critical in the event process as it directly impacts on the outcome and attainment of objectives of exhibitors and visitors. Seaton and Bennet (1996) argue that trade fairs which are managed by professional bodies and exhibition companies focus on promoting commercial activity or stimulating demand in a low season. The two authors on the contrary observed that exhibitions organized by state authorities tend to concentrate on matters of national prestige hence are characterized by the tendency of ignoring the objectives of exhibitors. This is likely to frustrate fair participants' initiative and support that may be necessary for a successful fair. It appears the private sector is not adequately involved in organising mega events such as the Sanganai/Hlanganani Travel Fair. Stakeholders have expressed the need to be involved in a more meaningful way in the planning and organization of the event (Mhizha, Mandebvu, Muzondo, \& Nyaruwata, 2013 , p. 118). The HAZ has little involvement except perhaps to exchange information on visitors who are booked with their members. In addition, the participation of all other ZCT-affiliated associations such as the AZTA, BAR, BAZ, CEAZ, ITOZA, SOAZ, ZVRA, and ZTOA in organising Sanganai/Hlanganani Travel Fair is minimal. The minimal involvement of the private sector in the planning of the expo means that the state agency, ZTA, which has the duty to organise and host the trade fair often does so without adequate resources given the budgetary constraints facing the government. The ZTA also lacks adequate expertise to efficiently organise the fair. It has often failed to have the Sanganai/Hlanganani Travel Fair arrangements completed before the start of the fair as a result of these challenges. Therefore, the fair presents the public and private sectors in Zimbabwe with a unique opportunity for establishing a PPP.

\section{Literature Review and Conceptual Framework}

The concept of PPPs is being adopted world-wide as a model of promoting national development (Khanon, 2010; Asian Development Bank, 2008; Grigorescu, 2008; Ng \& Wong, 2007). This is because many governments need to deliver services to their citizens but are faced with constrained fiscal budgets. PPPs have been seen as successful and beneficial even for social infrastructure development purposes (Khanon, 2010). Many researchers and practitioners are convinced that PPPs are a good mechanism to enable governments to deliver value-for-money public services (Ng \& Wong, 2006). Private participation in public infrastructure and services brings in financial investment, which is the main component of PPPs. This reduces the burden of government for financial resources and allows governments to reduce taxes or/and redeploy financial resources to other needy areas (Asian Development Bank, 2008; Jefferies, 2006; Ng \& Wong, 2006). Other attractions include transfer of skills, experience and expertise to achieve effectiveness and efficiency in planning, implementation, performance, costs, quality and delivery. Productivity and professionalism increase through creative alliance cooperation and reduced administrative overhangs. Competitive situation and advantage stand a good chance of improvement (Vijayanand, 2013). 
It is therefore no surprise that authorities in Zimbabwe are talking about establishment and development of PPPs. The country's tourism and hospitality industry could benefit tremendously from the PPPs both in terms of infrastructural projects and the organizing and staging of mega events such Sanganai/Hlanganani Travel and Tourism Fair. A number of developing countries have taken up the initiative in a big way. In South Asia, 501 new infrastructure projects with private participation were registered between 2000 and 2010 with 102 of these projects being recorded in 2010 (Izaguire, 2011, World Bank Group PPI Data Update Note 55). In contrast, the Update Note reveals that Sub Saharan Africa registered 249 such projects during the same period with only 13 being recorded in 2010. The Update Note continues to state that these projects attracted a total of $\$ 267.1$ billion in South Asia between 2000 and 2010 with $\$ 73.5$ billion being recorded in 2010 alone compared to $\$ 105.8$ billion in Sub Saharan Africa over the same period of which only $\$ 12.6$ billion was recorded in 2010. South Asia increased its infrastructure projects under PPPs five-fold i.e. from 20 in 2002 to 102 in 2010, while Sub Saharan Africa increased by 1.4 times from nine in 2002 to 13 projects in 2010, according to the Update Note. In another contrast in the Update Note is that Latin America and the Caribbean registered 688 projects with a financial package of $\$ 400.1$ billion. This in many ways points to the fact that countries in Sub Saharan Africa, Zimbabwe included, are failing to attract and establish PPPs in a big way.

\subsection{Challenges Affecting Establishment and Sustainability of PPPS}

Existing literature highlights a number of challenges that impede the successful establishment and implementation PPPs in a country. We list the commonly stated challenges in the literature and the authors citing them in Table 1 below.

\subsubsection{Lack of Trust}

Trust is a critical ingredient to the successful establishment and sustainability of PPPs. Lack of trust among partners brings about uncertainty in the PPP arrangement (Ng \& Wong, 2006; Grigorescu, 2008). Ng and Wong (2006) infer that one of the partners may have no confidence that the other party will act in good faith when they point out that performance problems may result from lack of trust. This is a dangerous situation as this prevents cooperation and cohesion needed in this arrangement.

Table 1. Challenges impeding establishment of PPPs

\begin{tabular}{|c|c|}
\hline Impediment & Author(s) supporting \\
\hline Lack of trust & Grigorescu (2008), Ng \& Wong (2007) \\
\hline Lack of incentives & $\begin{array}{l}\text { Gabriela et al. (2013), Jefferies (2006), Ng \& Wong. (2007), } \\
\text { Vijayanand (2013), Guzman \& Sierra., (2012), Googins and } \\
\text { Rochlin (2000), }\end{array}$ \\
\hline Risk and uncertainty & Gabriela et al. (2013), Sader (2000) \\
\hline $\begin{array}{l}\text { Lack of legal protection/partnership } \\
\text { framework }\end{array}$ & $\begin{array}{l}\text { Vijayanand (2013), Gabriela et al. (2013), Ng \& Wong (2007), } \\
\text { Thomsen (2005), De Lacey et al. (2002), Sader (2000) }\end{array}$ \\
\hline $\begin{array}{l}\text { Lack of initiative by prospective private } \\
\text { partners }\end{array}$ & Grigorescu (2008) \\
\hline Lack of government initiative and support & Grigorescu (2008), De Lacey et al. (2002), Lipsey $(2008,1995)$ \\
\hline $\begin{array}{l}\text { Adequate support and willingness to assist } \\
\text { private players whenever necessary }\end{array}$ & Vijayanand (2013), Griegorescu (2008), Jefferies (2008) \\
\hline Willingness to cooperate & Guzman \& Sierra (2012), Kolzow (1994) \\
\hline
\end{tabular}

\subsubsection{Lack of Incentives}

$\mathrm{Ng}$ and Wong (2006) point out that lack of real incentives for the private partner impedes PPP arrangements and establishment. The private partner requires clearly stated incentives that can be relied on for financial benefit and control (Gabriela et al., 2013; Jefferies, 2006; Ng \& Wong, 2006). Where the envisaged PPP is not believed to be beneficial to the private sector, it would be difficult to establish a PPP. Incentives, profits, sharing of risks and clear rights and concessions are examples of the benefits sought by the private sector (Vijayanand, 2013; Guzman \& Sierra, 2012; Googins \& Rochlin, 2000).

\subsubsection{Risk and Uncertainty}

Both public and private partners aim to share risks in the PPP project. Shifting of some project risks to private 
sector is one of the key aspects that motivate governments into PPPs. In this case public sector may be willing to offer an incentive (Jefferies, 2006; Grimsey et al., 2002). Risks involved are failure to pay partner, failure to implement, failure to perform, lack of resources, failure to assure a conducive environment (mainly political) and many more. If there is disagreement on the sharing of risks the partnership will fail (Gabriela et al., 2013). Conflicting project aims or objectives also bring about uncertainty in the subsistence of the PPP arrangement (Sader, 2000). When the whole PPP arrangement is too complicated this increases risk to particularly the private partner. The lack of success in PPPs in other areas of the economy will create uncertainty in the minds of parties wanting to establish a PPP (Gabriela et al., 2013). They go on to reveal that the Montreal Olympic Games organisers suffered a huge loss when they spent \$2 billion instead of the budgeted \$310 million in 1976. This scared private sector players in future games. The 1984 Los Angeles Games were however a huge success as they received tremendous private sector participation (Gabriela et al., 2013).

\subsubsection{Lack of Legal Protection/Partnership Framework}

Partners should know their expected responsibilities, duties, authority, rights, benefits and any limitations and obligations before the PPP is set up and implemented. This requires clear and detailed statutory arrangements (frameworks) and business plans. These instruments should spell out clearly the award procedures, how conflicts will be resolved, relevant regulations, public governance issues. Partners particularly should feel protected (Vijayanand, 2013; Gabriela et al., 2013; Ng \& Wong, 2006; Thomsen, 2005; De Lacey et al., 2002; Sader, 2000). Grigorescu (2008) contends that the absence of free initiative by the private partner because of 'bureaucratic character and regulation' on the part of the public sector, will impede establishment and implementation of PPPs

\subsubsection{Lack of Government Initiative and Support}

PPP projects ordinarily have to be initiated and properly supported by the public authority (Grigorescu, 2008). The government is the party with the immense responsibility to deliver public goods and services, so it is duty-bound to initiate arrangements with the private sector to produce these (De Lacey et al., 2002). The goods and services such as utilities would require the private sector to be properly motivated in order to be involved in them, otherwise the sector is normally not interested (Lipsey, 1995 \& 2008). Further, the public authority should promise adequate support and willingness to assist the private player whenever necessary (Vijayanand, 2013; Griegorescu, 2008; Jefferies, 2008). If the public sector does not seek private participation in this endeavour then no PPPs will be established. The PPP partners should have the willingness to cooperate and to get involved in order to form partnerships (Guzman \& Sierra, 2012; Kolzow, 1994).

Researchers and practitioners have put forward a number of cases in which various governments have attempted to remove some of the challenges or impediments towards PPP establishment and implementation. The Australian government has attempted to 'capture the benefits and issues/concerns' of the private sector in its Working with Government: Guidelines for Privately Financed Projects' (Jefferies, 2006). This development has assisted in enhancing confidence in government projects by private sector, as the guidelines broaden the relationships between PPP parties. Romania updated its 2004 law on private participation in line with European Union directives hence making the country a good destination for PPP investment (Gabriela et al., 2013). In Russia, the government actively sought private participation in its preparations for the 2014 Winter Olympic Games. As a result, the City of Sochi, which was the venue of the games, underwent massive transformation that gave it the potential to become one of the best international tourist destinations after the Olympics (Gabriela et al., 2013).

Governments have been encouraged to ensure that proper legal and operational frameworks are in place in order to attract more meaningful PPP projects. Asian Development Bank (2008) points out that strong PPP allocates the tasks, obligations, and risks among the public and private partners in an optimal way. The private sector has to feel confident to join the PPP. Governments should, therefore, allay private sector fears by formulating good policies, laws, regulations and selection procedures and practices. Further, required performance standards should not be complex and complicated in the eyes of the private sector. The private partners will avoid any arrangement that has a risk of requiring them to undertake anything that would reduce their competitiveness as a result of increased cost (Vijayanand, 2013; De Lacey, 2002; Swarbrooke et al., 1999). In addition to legal and policy modifications, governments seeking successful PPPs are expected to eliminate all possible challenges that can prohibit the establishment of PPPs and stifle PPP performance (Gabriela et al., 2013; Guzman \& Sierra, 2012; Mendiratta, 2010; Asian Development Bank, 2008).

\subsection{Conceptual Framework}

Drawing from the literature review above the researchers designed a conceptual framework of the probable challenges impeding the establishment and sustainability of PPPs in the tourism sector in Zimbabwe (Figure 1 
below). The conceptual framework comprises nine variables which we hypothesize may be impeding the establishment of PPPs in the country; the nine build on from the eight in Table 1 above.

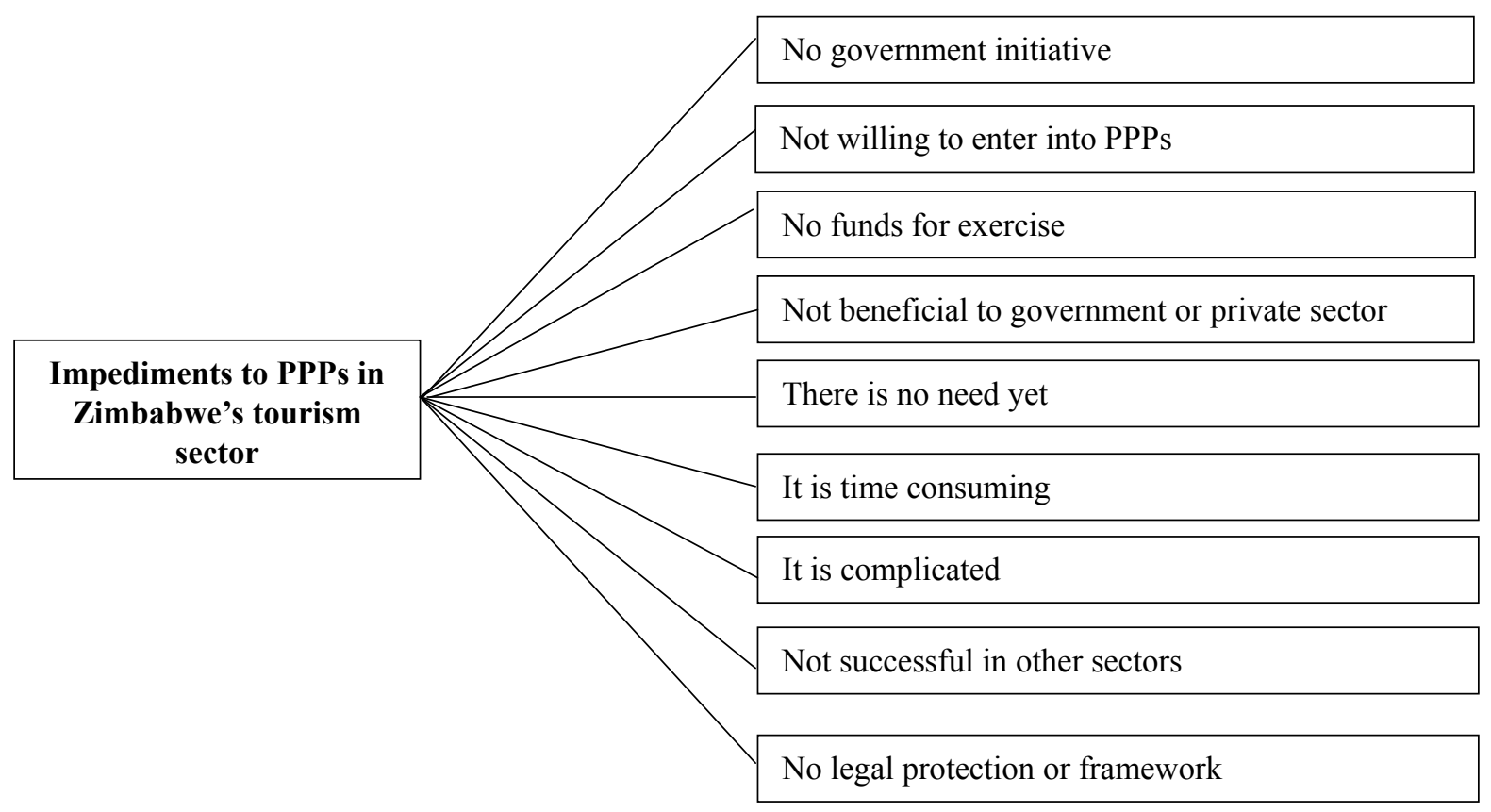

Figure 1. A conceptual framework of impediments to establishment and sustainability of tourism PPPs

Based on the nine constituent variables of the conceptual framework above we make the following hypotheses to be tested in the study:

$H_{l}$ : The public and private sectors have diverging perceptions on the statement that government takes no initiative to establish PPPs in the tourism sector in Zimbabwe'.

$\mathrm{H}_{2}$ : The public and private sectors have diverging perceptions on the statement that 'both public and private sectors in the tourism sector in Zimbabwe are not willing to enter into PPPs'.

$H_{3}$ : The public and private sectors have diverging perceptions on the statement that 'there are no incentives for entering into PPPs in the tourism sector in Zimbabwe'.

$H_{4}$ : The public and private sectors have diverging perceptions on the statement that 'PPPs in the tourism sector in Zimbabwe are not beneficial to the private sector'.

$H_{5}:$ The public and private sectors have diverging perceptions on the statement that there is no need yet for PPPs in the tourism sector in Zimbabwe'.

$H_{6}$ : The public and private sectors have diverging perceptions on the statement that 'PPPs in the tourism sector in Zimbabwe are time consuming'.

$H_{7}:$ The public and private sectors have diverging perceptions on the statement that 'PPPs in the tourism sector in Zimbabwe are complicated'.

$H_{8}$ : The public and private sectors have diverging perceptions on the statement that 'PPPs have not been successful in Zimbabwe'.

$H_{9}$ : The public and private sectors have diverging perceptions on the statement that 'there is no legal framework supporting PPPs in the tourism sector in Zimbabwe'.

\section{Methodology}

\subsection{Population, Sampling and Sample}

The target population for the study was organisations in the public and private sectors of the tourism industry in Zimbabwe which participated in the 2013 edition of the Zimbabwe International Travel and Tourism Expo held in Harare in October every year. From this population, the study's sample was 121 elements constituting of 33 respondents who are staff members in the Ministry of Tourism, ZTA, Parks and Wildlife (the public sector) and 
88 employees of ZCT member associations (private sector) who were manning the stands of their employers during the exposition. Thus the 121 respondents in our study are an accidental sample. This is "[a] sample gathered haphazardly, for example, by interviewing the first 100 people you ran into on the street who were willing to talk to you" (Vogt, 2004, p. 4). An accidental sample is a non-probability sample. The major weakness of an accidental sample is that researchers have no way of knowing what the population might be (Vogt, 2004). In this study Vogt's sentiments may be true in the context of ZCT members as they belong to various stakeholder groups within the tourism, leisure and hospitality industry as described in 2.1 above.

\subsection{Research Instrument}

We constructed a self-administered questionnaire to gather data to meet the study's two goals. The questionnaire had one thematic section: challenges impeding the establishment and sustainability of PPPs in the tourism sector in Zimbabwe. The thematic area was based on nine variables informed by extant literature as summarized in the conceptual framework in Figure 1 above. We constructed a five-point Likert scale ranging from Disagree Strongly (1) to Agree Strongly (5) to measure stakeholder perceptions on each of the nine variables in the conceptual framework. Given this range in the Likert-scale our mean for each variable is calculated as follows:

$$
\begin{aligned}
& \mathrm{M}=\sum \mathrm{n} / \mathrm{n} \\
& \mathrm{m}=(5+4+3+2+1) / 5 \\
& =15 / 5 \\
& =3
\end{aligned}
$$

This means that the cut-off mean for the items in the scale is 3 . Any mean score above 3 denotes that the respondents were agreeing with the statement and any mean score below 3 shows that they were disagreeing. We pre-tested the questionnaire and corrected it before conducting the full-scale survey. We used the drop-and-pick method to distribute the questionnaire during the three-days the exhibition ran. In all, we distributed 170 copies of questionnaire to public and private sector organisations that participated in the 2013 edition of Sangai/Hlanganani Travel Fair of which 121 useable questionnaires were returned.

\subsection{Data Input and Analysis}

We inputted data from the questionnaire into the Statistical Package for Social Sciences (SPSS) Version 22. We analysed the data using a number of statistical tools in SPSS. Using the dataset from the survey we initially tested the research instrument for reliability using Cronbach's coefficient alpha (Cronbach, 1951). "Reliability signifies the issue of consistency of measures, that is, the ability of a measurement instrument to measure the same thing each time it is used" (Singh, 2007, p. 77). Thus reliability is a measure of an instrument's ability to produce the same result each time it is used in subsequent investigations. Nunally (1978) suggests that a reliability coefficient alpha of 0.700 is acceptable but Santos (1999) observes that lower thresholds are sometimes accepted in the literature.

Thereafter, we analysed the data using descriptive statistics i.e. variable means and standard deviation. As already stated, variables with mean scores from 3 and above show that respondents were agreeing that they were indeed challenges to the establishment of PPPs and those with less than 3 indicate that respondents did not perceive them as impediments. Standard deviation signifies the spread of distribution (Singh, 2007, p. 115). In fact, it "is a measure of the spread based on all values, measuring the 'average' amount by which all values differ from the mean" (Lewin, 2005, p. 222). Dumba, Muzondo and Kaseke (2011, p. 74) argue that the lower the standard deviation the narrower the dispersion of respondents' views on that variable and the higher the standard deviation the wider the distribution of views.

We then analysed the data using inferential statistics i.e. paired samples $t$-tests. Paired samples t-test is computed at 95 percent level of significance ( $\mathrm{p} \leq 0.05,2$-tailed). Therefore, paired statements from any two samples with a $p$-value of less than 0.05 confirm that there is a substantial difference in the means between the two samples. We draw on samples $t$-tests to test the study's hypotheses presented in the conceptual framework above. Below we present and interpret the findings within the context of the study's goals using the statistical tools described above. The results are then discussed in section 5 .

\section{Findings}

\subsection{Instrument Reliability: Variable and Overall Cronbach Alphas}

As shown in Table 2 below, the lowest variable Cronbach coefficient alpha for the 9 items in our scale is .796 for the item "there is no need yet" and the highest is .808 for the variable "no legal protection". The overall alpha for the instrument is .824 . Following Nunally (1978) who suggests that a reliability coefficient alpha of .700 is 
acceptable, this means that our instrument is reliable. Thus the instrument can be used in future studies on PPPs in the tourism sector in Zimbabwe.

Table 2. Item and overall cronbach's alpha

\begin{tabular}{ll}
\hline Variable & Cronbach's Alpha \\
\hline No government initiative & .797 \\
Not willing to enter into PPP & .806 \\
No funds for the exercise & .832 \\
Not beneficial to government/private sector & .803 \\
There is no need yet & .796 \\
It is time consuming & .805 \\
It is complicated & .805 \\
Not successful in other sectors & .800 \\
No legal protection/framework & .808 \\
Overall Cronbach's Alpha & $\mathbf{8 2 4}$ \\
\hline
\end{tabular}

\subsection{Challenges Affecting Establishment and Sustainability of PPPs in Zimbabwe's Tourism Sector}

Given that our five-point Likert scale ranged from Disagree Strongly (1) to Agree Strongly (5), respondents from the public sector $(\mathrm{N}=33)$ agreed that only two of the nine items in the scale were, indeed, challenges in the establishment and sustainability of PPPs in the tourism sector in Zimbabwe because their mean scores are above the cut-off mean of 3 (Table 3 below) as explained in the methodology section above. The two items are "not willing to enter into PPPs" with mean score of 3.18 and "no incentives for PPPs" with mean of 3.88. The respondents from the public sector sub sample disagreed that all the remaining seven items in the scale were challenges because their mean scores range from a lowest of 1.48 for the item "there is no need yet" and to 2.85 for the variable "no government initiative". According to the scale, any mean score below 3 denotes that the respondents disagreed that the item concerned was a challenge to the establishment and sustainability of PPPs in the tourism sector in Zimbabwe. In other words, starting from the top of the table, respondents from the public sector are, in fact, implying that "government is taking the initiative to establish PPPs", "PPPs are mutually beneficial" to the public and private sectors, "there is need for PPPs now", "PPPs are not time consuming", "PPPs are not complicated", "PPPs are successful in other sectors", and "there is a legal framework supporting PPPs". This result, from the perceptions of public sector respondents, is a contradiction of our study's conceptual framework. We had consummated all the items in the scale to be challenges or impediments to the establishment and sustainability of PPPs.

Table 3. Perceptions on challenges affecting sustainability of PPPs in Zimbabwe's tourism and hospitality industry

\begin{tabular}{lllllll}
\hline Variable & Public Sector $(\mathbf{N}=33)$ & $\begin{array}{l}\text { Private } \\
(\mathbf{N = 8 8})\end{array}$ & Sector & Total (N=121) \\
& Mean & $\begin{array}{l}\text { Std. } \\
\text { Deviation }\end{array}$ & Mean & $\begin{array}{l}\text { Std. } \\
\text { Deviation }\end{array}$ & $\begin{array}{l}\text { Mean } \\
\text { Std. } \\
\text { Deviation }\end{array}$ \\
\hline No government initiative & 2.85 & 1.034 & 3.36 & 1.220 & 3.22 & 1.189 \\
Not willing to enter into PPP & 3.18 & 1.044 & 2.97 & 1.250 & 3.03 & 1.196 \\
No incentives/funds for the exercise & 3.88 & 1.111 & 3.33 & 1.127 & 3.48 & 1.146 \\
Not beneficial to government/private & 1.97 & .684 & 2.93 & 1.208 & 2.66 & 1.165 \\
sector & 1.48 & .508 & 2.45 & 1.180 & 2.18 & 1.122 \\
There is no need yet & 2.00 & .968 & 2.78 & 1.205 & 2.57 & 1.193 \\
It is time consuming & 1.88 & .696 & 2.99 & 1.121 & 2.67 & 1.133 \\
It is complicated & 1.76 & .751 & 3.36 & 1.078 & 2.92 & 1.230 \\
Not successful in other sectors & 2.39 & 1.116 & 3.14 & 1.077 & 2.93 & 1.135 \\
No legal protection/framework & & & & & \\
\hline
\end{tabular}


The standard deviations for the items in the scale with respect to perceptions of respondents from the public sector are the lowest compared to those from the 88 respondents from the private sector sample of the study and the two sub samples combined (see Table 3 above). The lowest standard deviation is .508 for the item "there is no need yet" and the highest is 1.116 for the variable "no legal framework". As evident in the table, five of the items have standard deviations between .508 and .968 . Nonetheless, responses on the same items from the private sector sub sample have standard deviations ranging from a lowest of 1.077 for the variable "no legal framework" to a highest of 1.250 for item "not willing to enter into PPPs". Standard deviation for the same items for the total or combined sample $(\mathrm{N}=121)$ range from lowest of 1.122 to a highest of 1.230 . Thus respondents from the public sector generally had a narrow dispersion of opinions towards the scale measure while the private sector, on one hand, and the combined sample, on the other, had a wide dispersion of views.

Variable mean scores for private sector respondents $(\mathrm{N}=88)$, however, show that they perceived four of the nine items in the scale as challenges to the development and sustainability of PPPs in the tourism sector in Zimbabwe. The four items have mean scores ranging from a lowest of 3.14 for "no legal framework" to a highest of 3.36 for items "no government initiative" and "not successful in other sectors" (Table 3) denoting that they are indeed impediments. Interestingly, the two sub samples' perceptions converge in only one of those very four items i.e. "there are no incentives" where private sector opinion has a mean score of 3.33 and public sector has a mean of 3.88. Their opinions diverge in three of the items with the private sector saying they are challenges (mean score greater than 3) vis-à-vis public sector opinion that they are not (mean score lower than 3); the items in question are "no government initiative", "not successful in other sectors", and "no legal framework".

The two sub samples' perceptions converge on four items i.e. "it is complicated", "it is time consuming", "there is no need yet", and "not mutually beneficial". This means that the two sub samples are disagreeing that these four are challenges. In other words, respondents in the two samples are, in actual fact, broadly agreeing that the variables are not challenges to initiation, establishment and sustenance of tourism PPPs in Zimbabwe.

There is consensus in the total sample $(\mathrm{N}=121)$ that only three of the nine items in the scale, the top three in Table 3, are, indeed, challenges in establishing and sustaining PPPs in the tourism sector in Zimbabwe. These three items have mean scores above 3, the cut-off point, denoting that the sample as a whole agrees they are challenges. The total sample is also disagreeing that all the remaining six items, mean score below the cut-off point, constitutes challenges in the establishment and promotion of PPPs. This means that those six variables are, in actual fact, not impediments or challenges at all.

5.3 Perception Gap between Public and Private Sector on Challenges to Establishment and Sustainability of Tourism PPPS

Table 4. Paired samples t-test on challenges facing PPPs in tourism sector

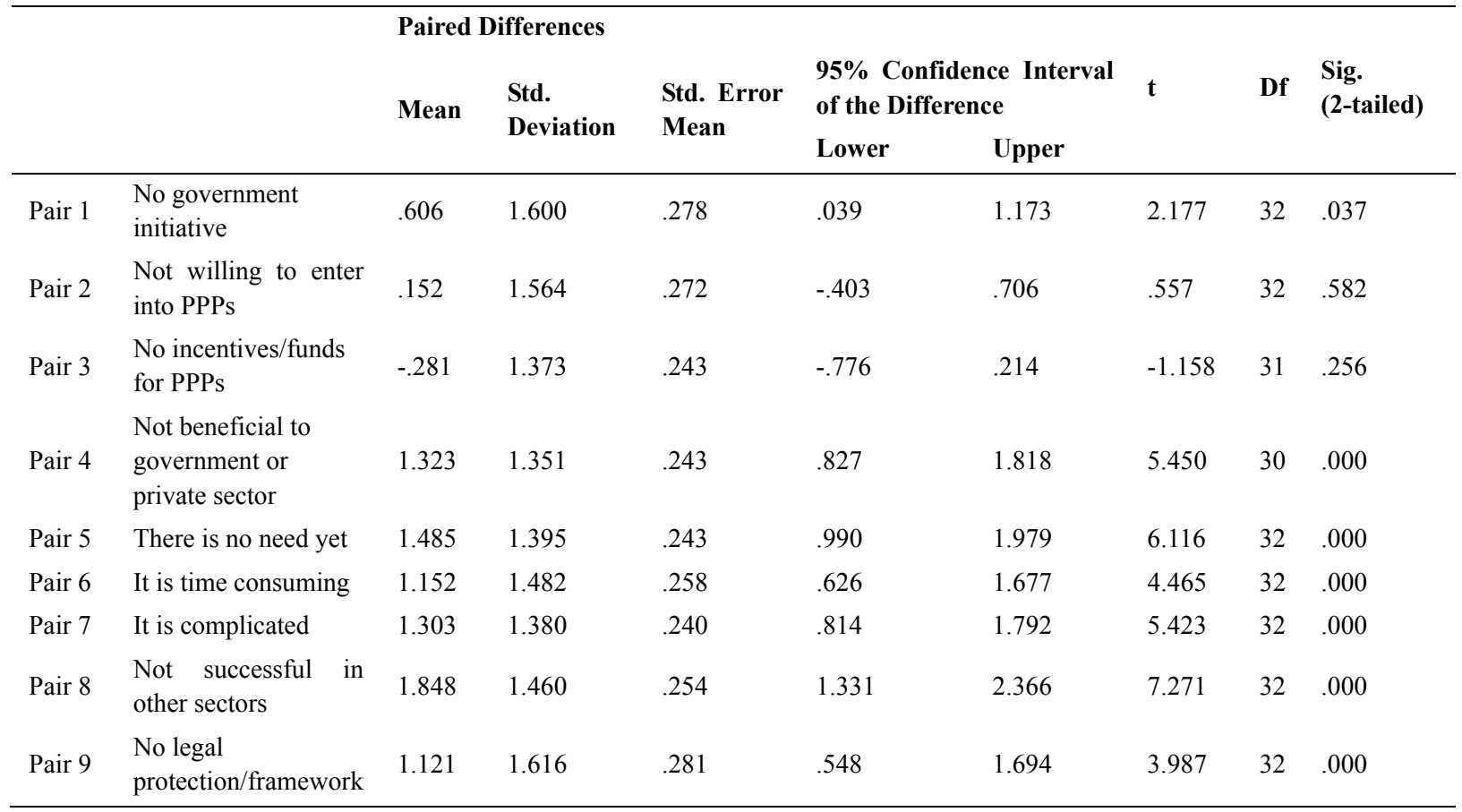


Considering that the survey gathered primary data from two sub-samples, public sector and private sector, and that the perceptions of the two samples by descriptive statistics, mean score in particular, varied in four of the nine items as already highlighted in Table 3 above, we subjected the dataset to paired samples $t$-test and the results are shown in Table 4 below. On the basis of the results of the paired samples $t$-test computed at 95 percent level of significance ( $\mathrm{p} \leq 0.05$, 2-tailed) we accept all but two of the study's hypotheses. Any result with a $p$-value of less than 0.05 shows that there is substantial difference in the means between the two samples. The p-value for Pair 2 is 0.582 and the p-value Pair 3 is 0.256 hence we reject hypotheses $H_{2}$ and $H_{3}$ on the basis of these results (Table 4). Hypotheses $\mathrm{H}_{2}$ and $\mathrm{H}_{3}$ are based on the two variables which the respondents affirmed were, indeed, challenges (Table 4).

At the same time, we accept all the remaining seven hypotheses of the study i.e. $H_{l}$ with a $p$-value of 0.037 and $H_{4}, H_{5}, H_{6}, H_{7}, H_{8}$, and $H_{9}$ with p-values of 0.000 . This means that there were material differences in perceptions of the two samples towards the seven above-stated variables on which these hypotheses are based. However, respondents also affirmed that the variable on which $H_{l}$ is based is also a challenge, while the variables on which all other six accepted hypotheses, $H_{4}$ to $H_{9}$, were not perceived as challenges. This contradicts our theoretical framework, which regarded all the nine variables as challenges. $\mathrm{H}_{8}$ has the highest $t$-value of 7.271 indicating the greatest magnitude of difference in perception among the two sub samples while $\mathrm{H}_{1}$, with the least $t$-value of 2.177 , depicts the least variance in opinion between the samples.

\section{Discussion, Conclusions and Implications}

\subsection{Discussion}

Governments generally lack sufficient financial resources to provide all public goods required by their citizens. Several governments have realised that PPPs can enable them to provide the goods if they partner with the private sector. Although the Zimbabwe government is promoting PPPs in infrastructure projects, the idea can be applied in the service context as well. PPPs offer the public sector opportunities to improve management effectiveness in planning and executing national activities of a non-tangible nature. For instance, the organising and managing of mega events in the tourism and hospitality sector in Zimbabwe could be significantly improved for the benefit of the private sector if public policy implementing agencies such as the ZTA adopted and extended the PPP concept into this area. This paper's major goal was to identify the challenges affecting the establishment and sustainability of PPPs in the tourism sector in Zimbabwe and the minor goal was to ascertain the gap, if any, in perceptions between the public and private sectors on impediments to the sustainability of tourism PPPs in the country. Given the results presented in the foregoing section, the objectives of the study were attained.

Only three out of the nine variables in the study's conceptual framework which were assumed to impede the establishment and sustenance of PPPs in the tourism and hospitality industry in Zimbabwe were confirmed to be challenges. The three variables are: "no government initiative", "not willing to enter into PPPs", and "no incentives for PPPs".

The public sector should generally take the initiative to establish PPPs (Grigorescu, 2008) as it has the responsibility to initiate partnerships with the private sector to produce public goods (De Lacey et al., 2002). The government is expected to provide an enabling business environment where the private sector can make profit. It appears the ZTA is yet to avail this benefit to the private sector in the country's tourism and hospitality industry through mega events such as the Sanganai/Hlanganani International Travel and Tourism Fair as it is yet to engage ZCT member associations at the strategic rather than operational level in planning and organising the fair. Mhizha et al. (2013) called for more stakeholder involvement in the organising and running of this exposition so the country's tourism and hospitality sector can fully benefit. Strong stakeholder involvement in crafting and implementing marketing communication strategies is critical as it strengthens the support ZTA gets from stakeholders (Nyambo, 2013). Exhibitions are part of the marketing communications mix.

At the strategic level, the Zimbabwe government has adopted a policy framework for promoting the establishment of PPPs in various sectors of the country. Nonetheless, at the operational level it appears some implementing arms of the government such as the ZTA are yet to adopt relevant strategies to facilitate the establishment of PPPs in their areas of focus. The public sector should explain the benefits of PPPs otherwise the private sector would not be interested. Lipsey $(2008,1995)$ admits that the private sector needs to be properly motivated in order to be involved in the production of public goods. The ZTA is blessed in that it has a private sector that is keen to participate in organising the mega events the authority is tasked to manage. So the opportunity for successful PPPs in the planning and management of mega tourism events in Zimbabwe are high.

All the remaining six variables in the study's conceptual framework were not perceived as impediments to the 
establishment of PPPs in the tourism and hospitality industry in Zimbabwe, contrary to what we had hypothesised in our conceptual framework. The variables are: "not beneficial to government and private sector", "there is no need yet", "it is time consuming", "it is complicated", "not successful in other sectors", "and no legal protection". In fact, we found that these six attributes rather reinforced the view that PPPs are beneficial to both the public and private sectors, there is need for PPPs, PPPs are not time consuming, PPPs are not complicated, PPPs are successful in other sectors, and there is a suitable legal framework for PPPs in Zimbabwe. The government realises that PPP arrangements are an effective way of spearheading various development projects in the country (Zimbabwe National Budget Statement, 2012) given the huge amount of financial resources needed which are clearly beyond its capacity.

The respondents in this study agreed that the variables "PPPs are time consuming" and "PPPs are complicated" were not impediments to the establishment and sustenance of PPPs in the tourism industry in Zimbabwe. Perhaps, PPPs may be perceived by the private sector as time consuming if the partnerships do not have clear benefits. In its Working with Government Guidelines for Privately Financed Projects, the Australian government captured the benefits and issues or concerns of the private sector (Jefferies, 2006). This is best practice as it shows the government's willingness to be transparent in its interactions with the private sector. PPPs should not be complicated to establish because governments that need them must expressly state that and put in place policies to help in the establishment of the partnerships. For example, the Zimbabwe government is working on guidelines for the receipt and procedure for determination of proposals for joint venture partnerships and similar arrangements in infrastructure projects such as roads, rails, energy, et cetera (Zimbabwe National Budget Statement, 2014).

Our conceptual framework's assumption that the public and private sectors in the tourism and hospitality industry were unwilling to enter into PPPs because they thought PPPs were not successful in other sectors was not supported by results of the survey. The respondents thought otherwise. Partners in PPPs must be willing to work together (Guzman \& Sierra, 2012; Kolzow, 1994) and the partnerships will be successful. The researchers' assumption that there was no legal framework guiding the establishment of PPPs in Zimbabwe was rejected by both public and private sector stakeholders in our sample. Indeed this also echoed the sentiment in the literature that the Zimbabwe government is putting in place the necessary legal framework for PPPs. Governments seeking successful PPPs should eliminate possible challenges which impede the establishment of PPPs or stifle PPP performance (Gabriela et al., 2013; Mendiratta, 2010). The Zimbabwe government for example, is fine-tuning the existing 2004 Policy Guidelines on Joint Venture partnership and similar arrangements to remove uncertainty and delays in the processing of projects, while at the same time giving clarity to prospective investors, thus making the investment opportunities more attractive (Zimbabwe National Budget Statement, 2014). Of course, in the case of Zimbabwe the prevailing negative perceptions on the Indigenisation Act among local and foreign investors may colour perceptions on PPP policy.

\subsection{Conclusions and Implications}

\subsubsection{Conclusions}

Many governments around the world are realising that PPPs are a viable pathway to national development. The objectives of this paper were to identify the challenges affecting the establishment and sustainability of PPPs in the tourism sector in Zimbabwe and to ascertain the gap, if any, in perceptions between the public and private sectors on variables impeding the sustainability of tourism PPPs in the country. The study attained both these goals.

Whereas the study's conceptual framework hypothesised that there were nine challenges impeding the establishment and sustainability of PPPs in the tourism and hospitality industry in Zimbabwe, only three of them were confirmed as such by the study's findings. The three variables are "no government initiative", "not willing to enter into PPPs", and "no incentives for PPPs". Respondents' perceptions confirm that these variables are indeed impediments. However, the remaining six of the variables were not viewed as challenges. The six attributes are: "not beneficial to government and private sector", "there is no need yet", "it is time consuming", "it is not complicated", "not successful in other sectors", and "no legal framework". Although these variables are critical to the establishment and sustainability of PPPs in the tourism sector, respondents did not perceive them as challenges. This implies that the negative wording in these six attributes has to be removed. Therefore, in view of the study's findings, we propose a tentative empirical model of PPP establishment and sustainability in Zimbabwe's tourism industry shown in Figure 2.

While the tentative empirical model still consists of nine variables just like the conceptual framework, it is different in that it divides the attributes into two clusters in line with the study's results. The left flank of the 
model comprises the three variables which respondents agreed were challenges or impediments to the initiation, establishment and sustainability of PPPs in the tourism sector in Zimbabwe. On the right side of the empirical framework are the six attributes of PPPs which the study's findings confirmed were not impediments. Therefore, we have had to rename the cluster of these variables as other variables. In addition, we have also had to rename the constituent variables in this cluster to "benefits of PPPs to partners", "needs driving PPPs", "PPP costs", "PPP procedures", "PPP success in other sectors", and "PPP legal framework" in order remove the somewhat negative connotations in the conceptual framework. Nonetheless, given the study's findings, the variables are still just as critical in determining the successful establishment of PPPs in the tourism sector as had been hypothesised in the conceptual framework.

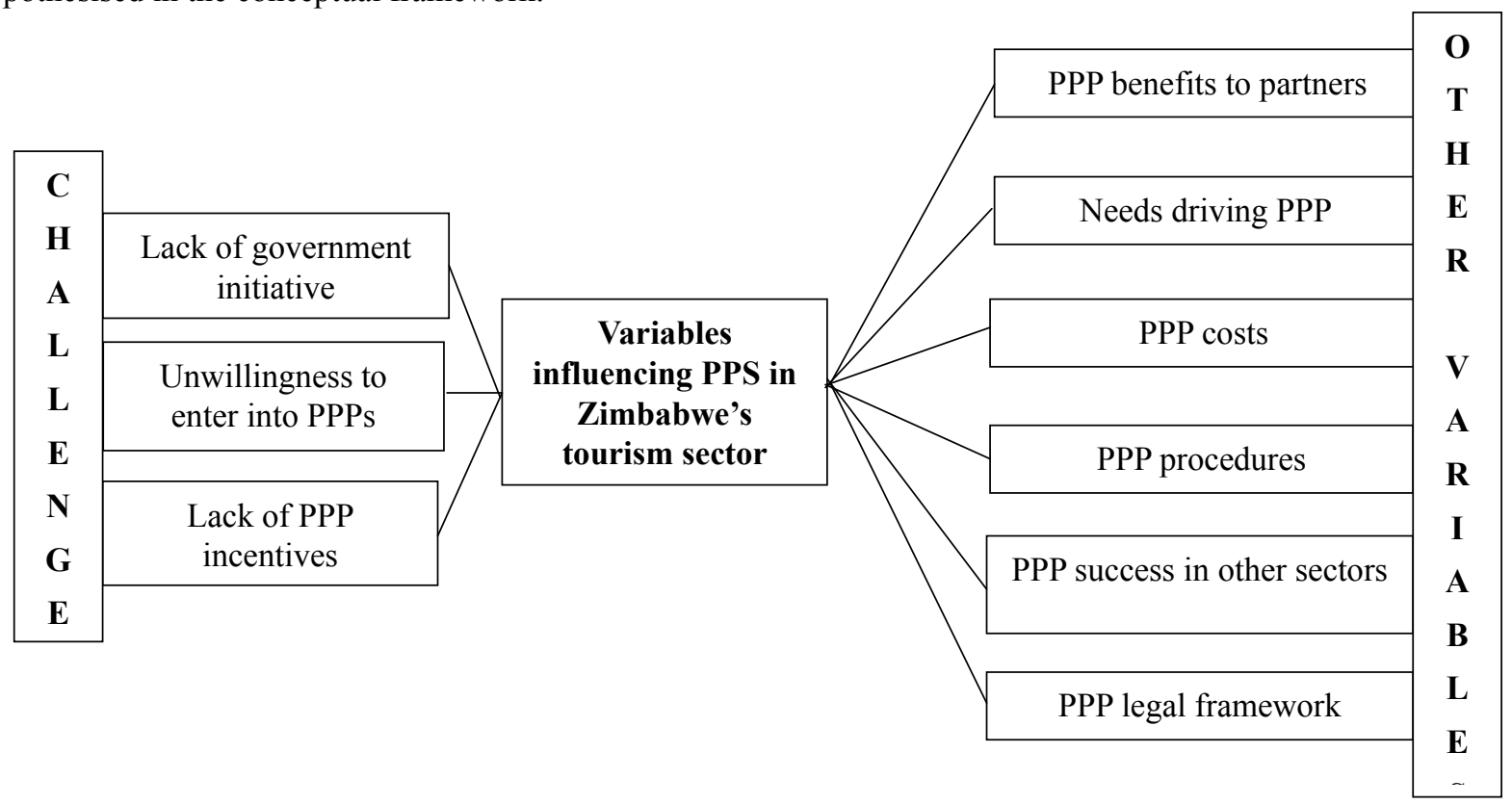

Figure 2. Tentative empirical model of PPP establishment and sustainability in Zimbabwe's tourism sector

\subsubsection{Academic and Public Policy Implications}

Although the results of the study have fundamental academic and public policy implications for the tourism sector in Zimbabwe, they should be treated as tentative given that our sample was accidental. The sample consisted of only 121 respondents employed in public and private sector organisations in the tourism and hospitality industry who participated in the 2013 edition of Zimbabwe's premier international tourism and travel exhibition, Sanganai/Hlanganani International Travel Fair. Consequently, the study's findings cannot be generalised to the population as accidental sampling, a non-random sampling technique, was used to select choose the respondents. The first academic implication of the paper is that future studies should test the study's tentative model of PPPs establishment and sustainability in Zimbabwe's tourism sector. Building on from the tentative model, the second academic implication of the study is that future studies should focus on determinants of successful PPP establishment and sustenance of PPPs in Zimbabwe's tourism sector.

The paper has a number of public policy managerial implications. One, the government needs to fine-tune its PPP policy as it promised in the Zimbabwe National Budget Statement (2014). Two, as the government fine-tunes the policy, it needs to give due consideration to views of the private sector otherwise the resultant PPP legal framework may still not enable the public sector to successfully court businesses into PPPs. Three, the government should ensure that the PPP policy coming out of this process is widely publicised through appropriate channels for prospective partners in the private sector locally and internationally to be aware of the opportunities. Four and lastly, the government needs to educate its policy implementing arms that PPP policy is flexible hence can be applied to any sector and area of management. At policy implementation level, this means that government agencies like the ZTA need to explore ways of involving the private sector in the planning and hosting of mega events. The ZCT and its many member associations are more than willing to be taken as partners in these activities. 


\section{References}

Advisory Services Occasional Paper 12, The International Finance Corporation and World Bank.

Akintoye, A., Beck, M., \& Hardcastle, C. (2003). Public-Private Partnerships: Managing Risks and Opportunities. Oxford: Blackwell Science. http://dx.doi.org/10.1002/9780470690703

Anholt, S. (2005). Brand New Justice: How Branding Places and Products Can Help the Developing World (Revised ed.). Oxford: Elsevier Butterworth-Heinemann.

Antonsen, I. M. N. (2010). The stakeholders' involvement in the process of building and maintaining a destination brand. Dissertation of degree of Master in International Management, EBAPE.

Asian Development Bank. (2008). Public-Private Partnership Handbook, Publication Stock No. 071107. Manila, Philippines.

Blain, C., Levy, S. E., \& Ritchie, J. R. B. (2005). Destination branding: Insights and practices from destination management organizations. Journal of Travel Research, 43, 328-338. http://dx.doi.org/10.1177/004728750 5274646

Cronbach, L. J. (1951). Coefficient alpha and the internal structure of tests. Psychometrika, 16, 297-334. http://dx.doi.org/10.1007/BF02310555

De Lacey, T., Batting, M., Moore, S., \& Noakes, S. (2002). Puplic/Private Partnerships for Sustainable Tourism-Delivering a sustainability strategy for tourism destinations. APEC Secretariat, the Australian Cooperative Research Centre for Sustainable Tourism.

De Pelsmacker, P., Geuens, M., \& Bergh, J. V. D. (2001). Marketing Communications. Pearson Education: England.

Dinnie, K. (2009). Nation Branding: Concepts, Issues, Practice. Oxford: Butterworth-Heinemann.

Dinnie, K., \& Fola, M. (2009). Branding Cyprus: A stakeholder identification perspective. Seventh International Conference on Marketing, Athens Institute for Education and Research (ATINER). Athens, Greece, July 6-9.

Dumba, M., Muzondo, N., \& Kaseke, N. (2011). Factors affecting management communication effectiveness at primary schools in a failing economy-Zimbabwe. Business and Social Review, 1(4), 64-82.

Easterbrook, R. (1986). A Geography of Zimbabwe. Longman Zimbabwe.

Gabriela, T., Bogman, C. V., \& Bulin, D. (2013). Public-Private Partnership-a new path for tourism development. Retrieved from http://www.academia.edu/2386259/Public-Private_Partnership

Googins, B. K., \& Rochlin, S. A. (2000). Creating the partnership society: Understanding the rhetoric and reality of cross-sectional partnerships. Business and Society Review, 105(1), 127-144. http://dx.doi.org/10.1111/ 0045-3609.00068

Grigorescu, A. (2008). Models of public-private partnership projects in tourism industry.

Grimsey, D., \& Lewis, M. K. (2002). Evaluating the risks of public private partnerships for infrastructure projects. International Journal of Project Management, 20, 107-118. http://dx.doi.org/10.1016/S02637863(00)00040-5

Guzman, F., \& Sierra, V. (2012). Public-private collaborations: branded public services? European Journal of Marketing, 46(7/8), 994-1012. http://dx.doi.org/10.1108/03090561211230160

Hall, C. M. (1995). Introduction to Tourism in Australia: Impacts, Planning and Development (2nd ed.). South Melbourne: Longman Australia.

Holden, A. (2000). Environment and Tourism. Taylor and Francis: Routledge.

Holloway, J. C. (1994). The Business of Tourism. Longman.

Izaguire, A. K. (2011). Private Participation in Infrastructure. World Bank Group, Public-Private Infrastructure Advisory Facility, PPI data note 55, August 2011.

Jefferies, M. (2006). Critical success factors of public private sector partnerships: A case study of the Sydney SuperDome. Journal of Engineering, Construction and Architectural Management, 13(5), 451-462. http://dx.doi.org/10.1108/09699980610690738

Kasabov, E., \& Sundaram, U. (2011). A stakeholder approach to branding clusters: Pointers to a research agenda. Regional Studies, 1-14. 
Kavaratzis, M. (2012). From 'necessary evil' to necessity: Stakeholders involvement in place branding. Journal of Place Management and Development, 5(1), 7-19. http://dx.doi.org/10.1108/17538331211209013

Kellezi, J. (2013). The effectiveness of trade shows in global competition. European Academic Research, (3), 265-274.

Khanom, N. A. (2010). Conceptual issues in defining public private partnerships. International Review of Business Research Papers, 6(2), 150-163.

Kim, J. J. (2011). Branding Korea though collaborative strategies with the Olympic Movement. Dissertation for Executive Masters in Sports Organisation Management, Faculté des Sciences du Sport, Université de Poiters, France.

Kolzow, D. R. (1994). Public-private partnership: The economic development organization of the 90s. Economic Development Review, 12(1), 4-6.

Lewin, C. (2005). Elementary quantitative methods. In B. Somekh, \& C. Lewin (Eds.), Research Methods in the Social Sciences (pp. 215-225). Sage Publications: London.

Lipsey, R. G. (1995). An introduction to Positive Economics. Oxford University Press.

Lipsey, R. G. (2008). Positive Economics: The New Palgrave Dictionary of Economics (2nd ed.). Palgrave. http://dx.doi.org/10.1057/9780230226203.1312

Mendiratta, A. (2010). PPP-Partnering for tourism growth. CNN Task Group. Tourism advertising solutions \& knowledge.

Mhizha, A., Mandebvu, G., \& Muzondo, N. (2012). The impact of tourism on culture: Empirical evidence from Victoria Falls. International Journal of Marketing and Technology, 2(1), 1-31.

Mhizha, A., Mandebvu, G., Muzondo, N., \& Nyaruwata, S. (2013). An evaluation of the value associated with exhibiting at Sanganai/Hlanganani World Travel and Tourism Africa Fair in Harare, Zimbabwe: Research findings from the 2011 fair held at Rainbow Towers in Harare. International Journal of Physical and Social Sciences, 3(6), 102-119.

Middleton, V. T. C., Fyall, A., Morgan, M., \& Ranchhold, A. (2009). Marketing in Travel and Tourism. Butterworth-Heinemann.

Moilanen, T., \& Rainisto, S. (2009). How to Brand Nations, Cities and Destinations: A Planning Book for Place Branding. Hampshire/New York: Palgrave Macmillan.

Ng, T. S., \& Wong, Y. M. W. (2007). Payment and audit mechanisms for non-private funded PPP-based infrastructure maintenance projects. Construction Management and Economics, 25(9), 915-923. http://dx.doi.org/10.1080/01446190701544396

Nunnaly, J. (1978). Psychometric Theory. New York: McGraw-Hill.

Nyambo, E. M. (2013). An evaluation of marketing communication strategies used to combat negative destination image: A case of Zimbabwe. Unpublished Master of Strategic Marketing Dissertation, Faculty of Commerce, Department of Business Studies, University of Zimbabwe: Harare.

Organisation for Economic Cooperation and Development. (2012). Recommendations of the Council on Principles for Public Governance of Public-Private Partnerships. OECD, Paris.

Report by Government of Zimbabwe to the 5th session of the United Nations Commission on Sustainable Development. (1997, April).

Sader, F. (2000). Attracting foreign direct investment into infrastructure. Foreign Investment.

Santos, J. R. (1999). Cronbach's alpha: A tool for assessing the reliability of scales. Journal of Extension, 37(2). Retrieved from http://www.joe.org/joe/1999april/index.php

Sartori, A., Mottironi, C., \& Corigliano, M. A. (2012). Tourist destination brand equity and internal stakeholders: An empirical research. Journal of Vacation Marketing, 18(4), 327-340. http://dx.doi.org/10.1177/13567667 12459689

Seaton, A. V., \& Bennet, M. M. (1996). The Marketing of the Tourism products: Concepts, issues and cases. London: International Thomson Business Press.

Serringhaus, F. H. R., \& Rosson, P. J. (1994). International trade fairs and foreign market involvement: Review and research directions. International Business Review, 3(3), 311-329. http://dx.doi.org/10.1016/0969-5931 
(94)90008-6

Short Term Emergency Recovery Programme. (2009). Ministry of Economic Development, Government of Zimbabwe: Harare.

Singh, K. (2007). Quantitative Social Research Methods. New Delhi: Sage Publications India.

Swarbrooke, J., \& Horner, S. (1999). Consumer Behaviour in Tourism. Butterworth-Heinemann, Oxford.

Thomsen, S. (2005). Encouraging Public-Private Partnerships in the Utilities Sector: The Role of Development Assistance. OECD/DAF Investment Division.

Tourism \& Hospitality Industry. (2008). New trends in Tourism and Hospitality Management (pp. 487-497).

Tourism Act 1996 (Chapter 14:20). Government of Zimbabwe: Harare. The Zimbabwe Government Printers, Printflow (Pvt) Ltd, Harare.

Vijayanand, S. (2013). Stakeholders and public private partnerships role in tourism management. International Journal of Scientific and Engineering Research, 4(2).

Vogt, W. P. (Ed.). (2005). Dictionary of Statistics \& Methodology. Thousand Oaks: SAGE Publications.

World Travel and Tourism Council. (2011). Global Importance of Tourism. Brussels: World Travel and Tourism Council.

World Travel and Tourism Council. (2012). WTTC Global Summit 2012. Tokyo, Japan. Retrieved from http://www.sadc.int/member-states/zimbabwe; http://www.zimbabwetourism.net/index.php/festivals-events /sanganai-hlanganani

Zimbabwe Agenda for Sustainable Socio-Economic Transformation 2013-2018, Government of Zimbabwe: Harare.

Zimbabwe National Budget Statement 2009, Ministry Finance and Economic Development, Government of Zimbabwe: Harare.

Zimbabwe National Budget Statement 2012, Ministry Finance and Economic Development, Government of Zimbabwe: Harare.

Zimbabwe National Budget Statement 2013, Ministry Finance and Economic Development, Government of Zimbabwe: Harare.

Zimbabwe National Budget Statement 2014, Ministry Finance and Economic Development, Government of Zimbabwe: Harare.

Zimbabwe Tourism Authority. (2010). Tourism Trends and Statistics Report 2010. ZTA Planning, Research and Development Division: Harare.

Zimbabwe Tourism Authority. (2012). Report on GDP 2012. ZTA Planning, Research and Development Division: Harare.

\section{Copyrights}

Copyright for this article is retained by the author(s), with first publication rights granted to the journal.

This is an open-access article distributed under the terms and conditions of the Creative Commons Attribution license (http://creativecommons.org/licenses/by/3.0/). 